\title{
The Effect of Family and Community Leaders Partnership on the Improvement of Nutritional Status of Toddlers in Pekanbaru City
}

\author{
Rifa Yanti ${ }^{1}$, Nur Indrawaty Lipoeto ${ }^{2}$, Fadil Oenzil ${ }^{3}$, Hafni Bachtiar ${ }^{4}$ \\ ${ }^{1}$ Student of the Doctoral Program in Public Health, Andalas University, Padang, Indonesia \\ ${ }^{2,3,4}$ Faculty of Medicine, Andalas University, Padang, Indonesia
}

\begin{abstract}
The lack of community participation in health affects the high number of maternal mortality rate (MMR) and infant mortality rate (IMR) in Indonesia. Indonesian Demographic and Health Survey (IDHS) reported that in 2012 there was an increase MMR became 359/100,000 KH and MMR 69/1000 KH (BPPSDM, 2014). Solutions or alternatives that could be done is empowering the family and the community. They should be educated and equipped with the basic knowledge and skills, especially in the efforts of Public health field. They were actively involved from planning to implementation and decision making. The role of community leaders is very necessary to reflect the aspirations of the needs of the community (Widyanto, 2014). This study aims to improve the nutritional status improvement program in the Pekanbaru city through innovative programs of partnerships between families and community leaders. Reinforced by the awareness of families to take advantage of health care facilities in monitoring the development and growth of toddlers, as an indicator of nutritional status improvement towards good nutritional status. Design research was Community Experiment Research in this case is used True Experiment Design. There were experimental group and control group, where the sampling was done randomly (Random Sampling) (Sugiyono, 2013) to 81 respondents. This research was combined (mixed methods) where quantitative research would be supported by qualitative research. Novelty in this study was the existence of community leaders partnering with families so they may be able to directly engage actively in activities in the promotion and implementation of the program to improve the nutritional status of toddlers, able to provide social support, adds the dimension of time, energy and foster independence for the family in an effort to improve the nutritional status of toddlers. The existence of the role and functions of community leaders became a role model that are close to the family is needed at this time. Community leaders are able to invite family with the ability and self-awareness in improving the health level of the family members. The changes in mother's visit to health services and nutritional status improvement of the research results of these studies showed the $p$ value of $<0.05$, statistically showed that there is a significant relationship.
\end{abstract}

Keywords: Family, Community Leader Partnership, Nutritional Status.

\section{Introduction}

Lymphatic The nutritional problems on each member of the family is not only about food issues, knowledge and skills, but also dealing with other problems like malnutrition and low arrangement of multi-unit approach. So that the settlement process should be conducted holistically (Sediaoetomo, 2008).

United Nations Children's Fund (UNICEF) reports that in Indonesia there were 7.7 million tddlers. In the report, Indonesia is ranked fifth in the world among countries that have children with toddlers with growth process. The Government continues to improve the health of the citizens. Nutritional problems become the main focus, because it affects the achievement of one of the Millennium Development Goals (MDGs) by 2015 is reduced by two thirds the mortality rate in the campus (Natalia, 2012)..

Many studies have been conducted to determine and identify the nutritional problems in toddlers. Riskesdas (2010), following the indicators associated with the main indicators of the MDGs, showed that nationally there has been a reduction in the prevalence of malnutrition (weight for age) among toddlers from $18.4 \%$ in 2007 to be $17.9 \%$ in 2010 ..

The lack of community participation in the health field, as one of them, has an impact on the high number of maternal mortality rate (MMR) and infant mortality rate (IMR) in
Indonesia. Indonesian Demographic and Health Survey (IDHS) reported that there was an increase of MMR became 359/100,000 KH and IMR became 69/1000 in 2012. (Kemenkes BPPSDM, 2014).

Other efforts that could be done is the family and the community must be empowered (empowerment) by educating and equipped with the basic knowledge and skills, especially in the effort in the health field. They were actively involved from planning to implementation and decision making. The role of community leaders is very necessary so it could reflect the aspirations of the community needs (Widyanto, 2014).

The Department of Health has changed their paradigm became the healthy paradigm that was focus on preventive and promotive other than curative, and the ability to live a healthy life for every individual (Leny, 2010) .

One of public health efforts aimed at family approach and oriented to family empowerment, so that health services oriented to the health services that closer to family (family friendly Health Centre). (Muhlisin, 2012).

Family approachalways directed to the empowerment of family potential either independently, or with the help of others to solve the health problems faced by relatives or members. (Muhlisin, 2012).

The importance of family approach was based on the 


\section{International Journal of Science and Research (IJSR) \\ ISSN (Online): 2319-7064 \\ Index Copernicus Value (2013): 6.14 | Impact Factor (2014): 5.611}

empirical facts concerning the number of families in Indonesia which was increasing from year to year. In 1990 recorded 35-40 million families, while at the beginning of the 21st century the number doubled to 60-65 million families. These data indicate that the health of family members and the quality of family life became very related and significant, because the family occupies a position between the individual and society (BKKBN, 1998).

In other words, the health problems that occur in connection with the impact of nutritional problem is a shared responsibility. The solution is expected to be realized through a good partnership with related sectors, ranging from the central government, provincial, district, community, community leaders, until the family as the main unit (Mardikanto, 2013).

Research conducted by Nurnahdiaty (2011) mentions that the women who featured in the family can act as a provider of health. They were able to keep, care for, and decide effort to find alternative treatment for family members. In improving family health, women's roles as preventive and curative behavior provider is needed.

The synergy with that, the researcher assumed that the role of community leaders (The wife of RW leader or the wife of RT leader) in Pekanbaru City could provide a change to the independence of the family in improving the nutritional status of toddlers. Observation result indicated that the involvement of other elements, in this case the role of the wife of RW leader or the wife of RT leader, should be a priority to reduce the nutritional problem that occur in family members.

Novelty in this study was the existence of community leaders partnering with families to be able to directly engage actively in activities of the promotion and implementation of the nutritional status improving program for toddlers, able to provide social support, able to provide the dimension of time, energy and foster self-reliance for the family in an effort to improve the nutritional status of toddlers.

Profile of Riau Provincial Health Office in 2012 stated that the nutritional status of the community is one indicator of the public health level. To see the condition of public health level in an area, the good or bad is determined by nutritional status.

The same data showed that the nutritional problems in toddlers has not received special attention, so there still found nutritional problems that fluctuated from year to year. In addition, the implementation of the program was still about improving the growth of infants and toddlers, as well as a decreasing the number of morbidity and mortality. The actions was still preventive like neonatal visits by health workers, immunization, provision of vitamin A, increasing the use of exclusive breastfeeding and feeding breast milk complementary (complementary foods [MP] -ASI) for babies of poor families. Not so different from the data in 2013, the implementation of nutritional programs and the efforts that have been made in order to solve the malnutrition problem was tracking the cases and the discovery of new cases. Implementation was done by health workers by involving cadres and the community, but not yet focused on how and other efforts to reduce the data of toddlers with nutritional disorders, so there still found toddlers with the malnutrition disorders. Based on the data from Pekanbaru Health Department in 2013, there were 434 toddlers below the red line, which was located at 20 Public health centers in Pekanbaru city.

This study aims to improve the nutritional status improvement program in Pekanbaru City through innovative partnerships program between families and community leaders. Reinforced by the awareness of families to take advantage of health care facilities in monitoring the development and growth of toddlers, as an indicator of nutritional status improvement towards good nutritional status.

\section{Method}

The design of the research is the Community Experiment Research, in this case using True Experiment Design. There were experimental group and control group of the 81 respondents are mothers who have toddlers below the red line, where the sampling was done randomly (Random Sampling tehcnique) (Sugiyono, 2013 ).

This research was a combined research (mixed methods), quantitative research would be supported by qualitative research. Merging these two methods were used as empirical evidence to answer the formulation of research problems, so it would be able to gain a better and comprehensive understanding . (Sugiyono, 2013).

\section{Result}

The efforts to increase the role and the existence of others' help in any participation of empowerment activities would feel the benefit if there was motivation and encouragement from within theirself to obtain a change for something better.

The realization process of the development activities, became the main task of community leaders to identify various issues, including efforts to increase understanding through an informal education, which is full of innovation that could be perceived changes in the family and community.

The novelty in this research was the existence of community leaders partnering with families able to directly engage actively in activities of the promotion and implementation of the program of toddlers nutritional status improvement, able to provide social support, able to provide the dimension of time, energy and foster self-reliance for the family in an effort to increase the toddlers nutritional status improvement.

Table 1: The changes of Heath Service Visits in the control group and the intervention group 


\section{International Journal of Science and Research (IJSR) \\ ISSN (Online): 2319-7064}

Index Copernicus Value (2013): 6.14 | Impact Factor (2014): 5.611

\begin{tabular}{|c|c|c|c|c|c|c|c|}
\hline \multirow{3}{*}{ Group } & \multicolumn{5}{|c|}{$\begin{array}{l}\text { Respondents visit to Health } \\
\text { Service }\end{array}$} & \multirow[t]{2}{*}{ Total } & \multirow[t]{3}{*}{$\mathrm{p}$} \\
\hline & \multicolumn{2}{|c|}{ Not increase } & \multicolumn{3}{|c|}{ increase } & & \\
\hline & $f$ & $\%$ & $f$ & $\%$ & f & $\%$ & \\
\hline Control & 74 & 91,4 & 7 & 8,6 & 81 & 100 & \\
\hline Intervention & 64 & 79,0 & 17 & 21,0 & 81 & 100 & 0,047 \\
\hline Total & 138 & 85,2 & 24 & 14,8 & 162 & 100 & \\
\hline
\end{tabular}

The percentage of the change of respondent visits to health service in the intervention group was higher (21\%), compared to the control group (8.6\%), with a value of $p$ $<0.05$ statistically has significant association to the mother's visit to health service, as seen in the table above.

Social support from various parties has exceptional protection effect on health. Mutually supportive relationship will provide the impetus for the formation of patterns of behavior change towards healthier.

Maternal visits to health service is useful to know the growth and development or toddlers, the efforts of the presence of community leaders have a positive impact on various social change.

The stage strategy of health service visit could be described as below:

\begin{tabular}{|c|c|c|c|c|}
\hline $\begin{array}{c}\text { Componen } \\
t\end{array}$ & Activity & Interview & $\begin{array}{c}\text { Observatio } \\
\text { n }\end{array}$ & $\begin{array}{c}\text { Triangulatio } \\
\text { n Analysis }\end{array}$ \\
\hline $\begin{array}{l}\text { Strategy of } \\
\text { health } \\
\text { service visit }\end{array}$ & $\begin{array}{l}\text { - Health education } \\
\text { - Provide support } \\
\text { and motivation } \\
\text { - Provide assistance } \\
\text { toposyandutoincrea } \\
\text { se interestfor health } \\
\text { service visit }\end{array}$ & $\begin{array}{l}\text { Communit } \\
\text { y leaders } \\
\text { felt the } \\
\text { functions } \\
\text { and duties } \\
\text { to get } \\
\text { attention. } \\
\text { Efforts } \\
\text { which are } \\
\text { given to the } \\
\text { community } \\
\text { with health } \\
\text { problems } \\
\text { of toddler } \\
\text { interwoven } \\
\text { kinship. }\end{array}$ & $\begin{array}{l}\text { Community } \\
\text { leaders } \\
\text { received } \\
\text { support from } \\
\text { the health } \\
\text { department } \\
\text { and health } \\
\text { cadres in } \\
\text { activities of } \\
\text { assisting } \\
\text { respondent } \\
\text { in } \\
\text { motivating } \\
\text { the } \\
\text { importance } \\
\text { of visiting } \\
\text { the health } \\
\text { service in } \\
\text { order to } \\
\text { determine } \\
\text { the growth } \\
\text { and } \\
\text { development } \\
\text { of toddlers }\end{array}$ & $\begin{array}{l}\text { Cooperation } \\
\text { or } \\
\text { collaboration } \\
\text { among health } \\
\text { workers, } \\
\text { cadres and } \\
\text { community } \\
\text { leaders } \\
\text { strengthen the } \\
\text { presence of } \\
\text { the family } \\
\text { with health } \\
\text { problems, to } \\
\text { raise awareness and } \\
\text { aware } \\
\text { independence } \\
\text { in visiting } \\
\text { health service } \\
\text { to monitor the } \\
\text { development } \\
\text { of toddler }\end{array}$ \\
\hline
\end{tabular}

The research result showed that the partnership of respondents together with community leaders in effort to improve the nutritional status of toddlers received good response from related agencies, in this case health workers provide an appreciation of the innovation performed, in the interview mentioned that the government's efforts has been quite a lot in an effort to improve the nutritional status of toddlers, but with the presence of community leaders in research activities has never been conducted.

Correlation of each unit would be interconnected and provide meaningful change on the family and community, it would be easier to identify the problems that occur in the field. Community leaders would be instrumental in helping health activities along with related units according to its function.

The implementation stage that was conducted in this study, such as the respondents visit to the health service became indicators of achievement that was in need, health monitoring, increasing of nutritional status improvement, awareness of family or community etc are the result of the expected goals.

In an effort to improve the renewal program to reduce the number of toddlers with nutritional problem towards a healthy toddlers with good nutritional status, and would be a health program that could be used by the Public health center to the level of Posyandu. The programs featured community leaders to be the role models which close to the family to be able to invite family with self-awareness capabilities and improve the health level of the family members themselves.

Table 2: The average improvement of Toddler Weight (Kg) in the control group and the intervention group

\begin{tabular}{|c|c|c|c|c|c|c|}
\hline \multirow{2}{*}{$\begin{array}{l}\text { Toddlers } \\
\text { Weight }(\mathrm{Kg})\end{array}$} & \multirow[t]{2}{*}{ Total } & \multicolumn{2}{|c|}{ Average } & \multicolumn{3}{|c|}{ Average } \\
\hline & & Before & After & p & Difference & p \\
\hline Control & 81 & $\begin{array}{l}11,14= \\
1,22\end{array}$ & $11,49 \pm 1,30$ & 0,001 & $\begin{array}{l}0,35= \\
0,42\end{array}$ & \\
\hline Intervention & 81 & $\begin{array}{l}11,51 \pm \\
1,20\end{array}$ & $\begin{array}{l}12,02 \pm \\
1,16\end{array}$ & 0,001 & $\begin{array}{l}0,51 \pm \\
0,42\end{array}$ & 40,015 \\
\hline
\end{tabular}

The table above shows that the average weight of toddlers in the intervention group after treatment with the presence of community leaders increased by $12.02 \mathrm{Kg}$ (standard deviation 1.16), while in the control group after treatment without the presence of community leaders increased by $11.49 \mathrm{Kg}$ (standard deviation 1.30), the statistic test results obtained p value $<0.05$ means there is significant association of weight gain in toddlers before and after at the intervention and control groups.

The results are the effort and support given by the community leaders to family and health problems, especially toddlers with nutritional status problems.

The changes in weight gain and changes from the less become a better thing showed the existence of commitment of each respondent. Self-awareness and a willingness to increase the weight improvements of toddlers was made through the role and support of community leaders in their territories.

During the implementation phase, the weight of toddlers monitoring was done as an indicator of the success of efforts that have been made between the respondent and community leaders.

This stage is the final stage of the implementation of the conducted research. Evaluation of the changes in toddlers' body weight was measured again for obtaining significant results. Activity continued by making a deal and a shared commitment between rensponden and community leaders in efforts to improve toddlers' health status to monitor the weight improvement regularly. 


\section{International Journal of Science and Research (IJSR)}

ISSN (Online): 2319-7064

Index Copernicus Value (2013): 6.14 | Impact Factor (2014): 5.611

\begin{tabular}{|c|c|c|c|c|}
\hline Component & Activity & Interview & Observation & $\begin{array}{c}\text { Triangulation } \\
\text { Analysis }\end{array}$ \\
\hline $\begin{array}{l}\text { Measurement } \\
\text { of toddlers } \\
\text { wight }\end{array}$ & $\begin{array}{l}\text { - Measurement } \\
\text { of toddlers } \\
\text { wight before } \\
\text { the } \\
\text { implementati } \\
\text { on of the } \\
\text { research } \\
\text { - Measurement } \\
\text { of toddlers } \\
\text { wightafter } \\
\text { the } \\
\text { implementati } \\
\text { on of } \\
\text { research } \\
\text { (with } \\
\text { presence of } \\
\text { community } \\
\text { leaders } \\
\text { during the } \\
\text { research) }\end{array}$ & $\begin{array}{l}\text { Community } \\
\text { leaders } \\
\text { accompanied } \\
\text { by researcher } \\
\text { identified the } \\
\text { existence of } \\
\text { toddlers with } \\
\text { nutritional } \\
\text { problem, } \\
\text { identified by } \\
\text { less weight of } \\
\text { toddlers }\end{array}$ & $\begin{array}{l}\text { Identifying } \\
\text { toddlers with } \\
\text { the } \\
\text { incompatibilit } \\
\text { y of weight } \\
\text { based on age, } \\
\text { body weight } \\
\text { measurement } \\
\mathrm{s} \text { were taken } \\
\text { before and } \\
\text { after the } \\
\text { research } \\
\text { activities with } \\
\text { the assistance } \\
\text { of community } \\
\text { leaders }\end{array}$ & $\begin{array}{l}\text { From the } \\
\text { research } \\
\text { conducted } \\
\text { found } \\
\text { improvement } \\
\text { oftoddlers } \\
\text { weight results } \\
\text { with } \\
\text { attendance of } \\
\text { community } \\
\text { leaders higher } \\
\text { than without } \\
\text { the presence of } \\
\text { community } \\
\text { leaders }\end{array}$ \\
\hline
\end{tabular}

Monitoring of weight measurement was done before the implementation of the study (pre-study without the assistance of community leaders) and after the implementation of the research (with the presence of community leaders), as described in the matrix above.

\section{Discussion}

The presence of community leaders will change the paradigm of the family to be independent, in an effort to improve the nutritional status of children in the middle of family. This research provides a real solution for the government in an effort to encourage the involvement of community leaders from the female element that plays a role in each community member to assist the family in improving the health program, especially decreasing the number of toddlers with nutrition problems.

Community leaders are also involved in meeting the needs of health information (extension). In addition, they are expected to encourage all elements of community, so it becomes a strength and confidence of families and communities in understanding the meaning of health for each member of family.

Based on research conducted by Badake (2014) in Kenya, stated that the information on the nutritional status of children is an indicator of the nutritional situation in the community. The study tried to determine the nutritional status of toddlers and the associated factors in the District of South Mbeere in Kenya. A cross-sectional descriptive study was conducted using a structured questionnaire, obtained the result was a significant association between the size of the household menu settings with nutritional status $(P=0.047)$. The findings suggested that determination of nutritional status and food variety is essential to obtain good nutrition, interventions in the future needs to be improved for food access and the availability of a good menu.

\section{Conclusion}

The existence of the role and functions of community leaders to be a role model that is close to the family is needed at this time, community leaders were able to invite family with the ability and self-awareness in improving the health of the family members.

The changes in health service visits by the mother from the results of these studies showed the $\mathrm{p}$ value of $<0.05$, statistically showed that there was a significant association. Similarly, the improvement of nutritional status of children, the increase in toddlers weight before and after in the intervention groups with $\mathrm{p}$ value $<0.05$ was statistically also showed a significant association.

\section{References}

[1] Achmadi (2013), Public Health Theory and Applications, PT. Raja Grafindo Persada Jakarta

[2] Alderman.H and Meera Shekar,May 2010,"Nutrition, Food Security, and Health, FromWorldBank:Repositioning nutrition as central to development", Chapter43 Accessed May 23, 2010.

[3] Almatsier (2009),Basic Principles of Nutrition , PT Gramedia Pustaka Utama, Jakarta

[4] Arisman, (2002),Nutrition in the Life Cycle , EGC Jakarta

[5] Arikunto.S (2012), Procedure Research an Practice Approach, Rineka Cipta Jakarta

[6] Bayoa G.A (2013), Women's Participation in Policy Implementation Program Management and Family Welfare Society, e-jurnal Unstrat, Volume 5 Nomor 3, 2013

[7] Bhandari TR , Nutritional Status of Under Five Year Children and Factors Associated in Kapilvastu District ,Nepal, Department of Public Health, Faculty of Science and Technology, Pokhara University, Kaski, Nepal, Journal Nutrition Health Food Sci 1(1): Published: December 30, 2013

[8] Nutrition Development Agency in the Directorate of Nutrition (2013), The Ministry of Health of the Republic of Indonesia

[9] Badake Q.D ,Maina I ,Mboganie M.A , Muchemi G ,Nutritional Status Of Children Under Five Years And Associated Factors In Mbeere South District, Kenya , African Crop Science Journal, Vol. 22, ISSN 10219730, 2014

[10]BKKBN (2008), Gender Training Center for Women and Quality Improvement

[11] National Family Planning Coordinating Board, Jakarta

[12] Cangara.H (2012), Introduction to Communication Studies, PT Raja Grafindo Persada Jakarta

[13] Cahyaningsih.S (2011), Growth of Child and Adolescent Development, PT Trans Media Jakarta

[14]Creswell.J.W (2003), Research Design Qualitative, Quantitative, and Mixed Methods Approach, Sage Publication, London

[15]Dahlan. S (2010), Large Sample and Sampling Method, PT Salemba Medika Jakarta

[16]_ (2012), Statistics for Medical and Health, PT Salemba Medika Jakarta

[17] Muhlisin (2012),Family nursing , Gosyen Publishing, Yogyakarta

[18] Mardikanto.T \& Subianto.P (2013),Community Development in the Perspective of Public Policy, PT Alfabeta Bandung 
[19] Nurnahdiaty (2011), "Role of Women as Provider In The Effort Improving Taraf Banta Family Health in Sub-Bantaeng Makassar ", Department of Medical Record and Health Information Panakkukang Makassar, Department of Anthropology, Faculty of Social and Political Science, University of Hasanuddin

[20] Natalia(2013),Relationships Family Level Food Security And Nutrition Substance Adequacy Levels With Toddler In the village of Nutritional Status Gondangwinangun In 2012 the Journal of Public Health, 2013, Volume 2, Number 2, April 2013 Online athttp://ejournals1.undip.ac.id/index.php/jkm

[21] Sugiyono (2013), Research Methods Combination(Mixed Methods), PT Alfabeta Bandung

[22] Sediaoetama (2008), Science of nutrition, PT Dian Rakyat Jakarta

[23] _ (2009), Science of nutrition, PT Dian Rakyat Jakarta

[24] Widyanto (2014),Community Nursing Practical Approach,Nuha Medika Yogyakarta

\section{Author Profile}

Rifa Yanti, Student of Public Health Doctoral Program at Andalas University, Padang, Indonesia. She received the nurse degree from Andalas University in 2003 and M.Biomed degree from Andalas University, Padang, Indonesia in 2010. She is a Lecturer in STIKES Al Insyirah, Pekanbaru, Riau, Indonesia. 